\title{
Fracture Toughness and Crack Resistance of Steam Pipeline Steel in Initial and Used States
}

\author{
M. Zrilic, ${ }^{a}$ Z. Burzic, ${ }^{b}$ and Z. Cvijovic ${ }^{a}$ \\ a Belgrade University, Faculty of Technology and Metallurgy, Belgrade, Serbia and \\ Montenegro \\ ${ }^{\mathrm{b}}$ Military Technical Institute, Belgrade, Serbia and Montenegro
}

УдК 539.4

\section{Вязкость разрушения и трещиностойкость стали паропровода в исходном состоянии и после эксплуатации}

\author{
М. Зрилича", 3. Бурзич ${ }^{6}$, 3. Цвийовича

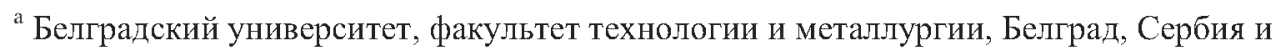 \\ Черногория

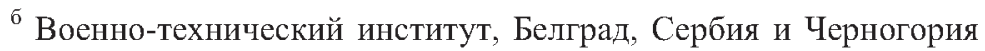 \\ Исследуется проблема преждевременного разруиения паропроводов (сталь 14MоV6 3) с \\ расчетным ресурсом 100 mыс. ч при температуре $540^{\circ} \mathrm{C}$. При изготовлении эксперимен- \\ тальных образцов использовалась сталь в исходном состоянии и после 117 mьсс. ч эксплу- \\ атации. Применение локального подхода механики разруиения и металлографического ана- \\ лиза наряду с классическими методами (испьтания на растяжение, трещиностойкость, \\ усталостную прочность) позволило более точно оценить деградацию свойств стали под \\ действием высоких температур и напряжений. Обоснована необходимость дальнейшего \\ развития локального подхода к прогнозированио условий разрушения материалов при дли- \\ тельной эксплуатачии в условиях высоких температур.
}

Ключевые слова: паропровод, разрушение, локальный подход механики разрушения, металлографический анализ, испытания на растяжение, трешиностойкость, усталостная прочность.

Introduction. In late seventies, application of 14MoV6 3 steel (DIN) for highly loaded steam pipelines (temperature up to $540^{\circ} \mathrm{C}$ and pressure as high as 45 bar for service life of 100,000 hours) offered significant benefits compared to the steels of previous generation $[1,2]$ and allowed reduction of pipe wall thickness.

However, frequent premature failures of steam lines produced of this steel, sometimes after only 30,000 service hours, imposed the necessity to retrofit damaged steam pipelines, e.g., steam lines of thermoelectrical power plants in Greece [3]. This unexpected repair cost hampered further application of 14MoV6 3 steel and the designers preferred to replace it by other, highly alloyed steels (e.g., alloyed steel X12 CrMoV 1, according to DIN, and low alloyed steel 10CrMo9). There is no clear explanation for failure occurrence, and steel 
producers claim that steel $14 \mathrm{MoV} 63$ is a proper one for the intended application [2]. Better understanding of in-service behavior of 14MoV6 3 steel can help in reducing forced shutdowns and improve the reliability and service safety of thermoelectric power plants.

The rate of deterioration of properties and their level after long-term service at high temperature is of importance for the evaluation of residual life and the decision about next service of damaged pipes [4]. For that, experimental analysis is performed in order to get more insight in $14 \mathrm{MoV} 63$ steel properties' deterioration.

The rate of deterioration of properties can be assessed by comparing the data of new and used steel. In addition to microstructure, mechanical and creep properties, resistance to fracture has to be analyzed, applying fracture mechanics and fatigue tests, as well as a new developed method based on local approach to fracture $[5,6]$. The latter relates the local stresses and strains in the considered component volume to the mechanical damage parameters, directly depending on material microstructure and fracture micromechanisms. The fracture parameters, so far developed and recommended by standards, such as stress intensity factor $K_{\mathrm{I}}$ or $J$-integral, cannot confidently define and predict the behavior of materials under external load in all conditions. Hence, a local approach to fracture is introduced as a promising one, developed in theoretical, experimental and numerical consideration of different stress concentration levels [7]. The purpose of applying the local approach is to define more accurate and less conservative material characteristics. This can be achieved by accurately determined stresses, strains and variables, which describe physical damage mechanisms in cracked material.

The specimens, produced from samples taken of new (initial) and old (used) 14MoV6 3 steel have been tested. Mechanical properties are evaluated by tensile and impact tests. Resistance to fracture has been determined by fracture mechanics testing, fatigue crack growth rate determination and by local approach, analyzed for ductile fracture properties, which is dominant in the considered case.

Determination of Material Properties. Material and Specimen Preparation. Specified chemical composition of 14MoV6 3 steel according to standard DIN 17175 is given in Table 1 . The mechanical properties, as prescribed by standard DIN 17175, are given in Table 2.

$\mathrm{T}$ a b 1 e 1

Chemical Composition of 14MoV6 3 Steel

\begin{tabular}{|c|c|c|c|c|c|c|c|c|}
\hline DIN & C & Si & Mn & P (max) & S (max) & Cr & Mo & V \\
\hline 17175 & $0.10-0.18$ & $0.15-0.35$ & $0.30-0.60$ & 0.035 & 0.035 & $0.30-0.60$ & $0.50-0.65$ & $0.25-0.35$ \\
\hline
\end{tabular}

$\mathrm{T}$ a b 1 e 2

Mechanical Properties of 14MoV6 3 Steel at Room Temperature

\begin{tabular}{|c|c|c|c|c|c|}
\hline $\begin{array}{c}\text { Tensile } \\
\text { strength } \\
R_{m}, \mathrm{MPa}\end{array}$ & $\begin{array}{c}\text { Yield } \\
\text { stress } \\
R_{e}, \mathrm{MPa}\end{array}$ & $\begin{array}{c}\text { Longitudinal } \\
\text { elongation } \\
A_{l}, \%\end{array}$ & $\begin{array}{c}\text { Transverse } \\
\text { elongation } \\
A_{t}, \%\end{array}$ & $\begin{array}{c}\text { Longitudinal } \\
\text { impact energy } \\
E_{l}, \mathbf{J}\end{array}$ & $\begin{array}{c}\text { Transverse } \\
\text { impact energy } \\
E_{t}, \mathrm{~J}\end{array}$ \\
\hline $490-690$ & 365 & 20 & 18 & 62 & 41 \\
\hline
\end{tabular}


The samples of 14MoV6 3 steel were taken from new and used pipes $(D \times t=609 \times 40 \mathrm{~mm})$, with drawn from service after 117,000 service hours at maximum $540^{\circ} \mathrm{C}$ under pressure of 42 bars in steam pipeline because of detected serious damage in elbows and welded joints.

Following specimens (Fig. 1) have been taken from samples for:

- tensile testing - ST;

- impact toughness testing - FT;

- local-fracture-approach testing: with notch root radius $2 \mathrm{~mm}-\mathrm{NT} 2,4 \mathrm{~mm}$ - NT4, and $10 \mathrm{~mm}$ - NT10;

- $J$-integral fracture toughness testing - SE(B);

$-d a / d N$ - fatigue crack propagation assessment - FT.

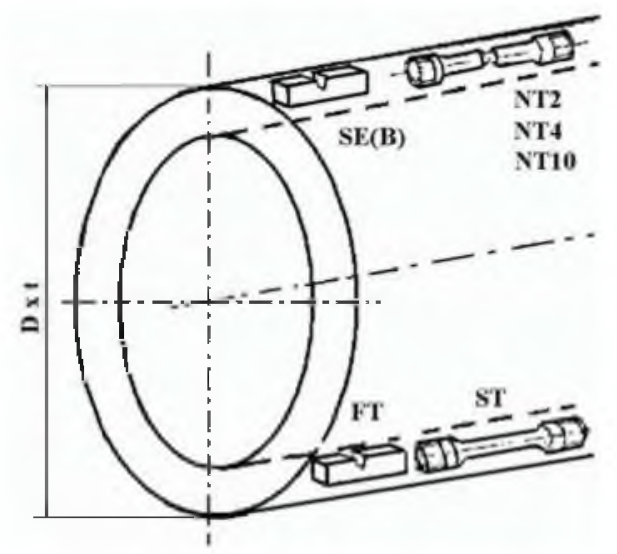

Fig. 1. Samples and specimens made from pipes.

Chemical Composition of Tested Material. Chemical composition of new and used material is given in Table 3.

$\mathrm{T}$ a b 1 e 3

Chemical Composition of 14MoV6 3 Steel

\begin{tabular}{|c|c|c|c|c|c|c|c|c|}
\hline Steel & $\mathrm{C}$ & $\mathrm{Si}$ & $\mathrm{Mn}$ & $\mathrm{P}(\max )$ & $\mathrm{S}(\max )$ & $\mathrm{Cr}$ & $\mathrm{Mo}$ & $\mathrm{V}$ \\
\hline new & 0.13 & 0.20 & 0.36 & 0.014 & 0.021 & 0.55 & 0.51 & 0.28 \\
\hline used & 0.12 & 0.21 & 0.36 & 0.013 & 0.019 & 0.56 & 0.49 & 0.31 \\
\hline
\end{tabular}

Tensile Properties of Initial and Used Steels. Tensile properties of new and used 14MoV6 3 steels are determined by testing smooth standard specimens at 150 and $250^{\circ} \mathrm{C}$. Mechanical properties at $150^{\circ} \mathrm{C}$ are necessary as basic data for $J$-integral determination. It is noteworthy that tensile properties of this class of steels have similar values in the range from room temperature up to $150^{\circ} \mathrm{C}$. The temperature of $250^{\circ} \mathrm{C}$ is selected for plastic analysis within the local approach framework. Typical plots obtained in tensile testing are presented in Fig. 2, and corresponding values are listed in Table 4.

In general, tensile properties of used steel are still not critical regarding next service. The effect of elevated temperature under operating stresses on tensile properties of steel $14 \mathrm{MoV} 63$ is more pronounced in the yield stress than in 
tensile strength. The difference between yield stress and the ultimate tensile strength is more pronounced at higher testing temperature $\left(250^{\circ} \mathrm{C}\right)$. The elongation reduction value is of the same level at both testing temperatures.

$\mathrm{T}$ a b 1 e 4

Mechanical Properties of New and Used 14MoV6 3 Steels at 150 and $250^{\circ} \mathrm{C}$

\begin{tabular}{|c|c|c|c|c|c|c|}
\hline Steel & $\begin{array}{c}\text { Temperature, } \\
{ }^{\circ} \mathrm{C}\end{array}$ & $\begin{array}{c}\text { Tensile } \\
\text { strength } \\
R_{m}, \mathrm{MPa}\end{array}$ & $\begin{array}{c}\text { Yield } \\
\text { stress } \\
R_{e}, \mathrm{MPa}\end{array}$ & $\begin{array}{c}\text { Longitudinal } \\
\text { elongation } \\
\varepsilon_{l}, \%\end{array}$ & $\begin{array}{c}\text { Radial } \\
\text { elongation } \\
\varepsilon_{d}, \%\end{array}$ & $\begin{array}{l}\text { Young's } \\
\text { modulus } \\
E, G P a\end{array}$ \\
\hline new & \multirow[t]{2}{*}{150} & 490 & 338 & 20.6 & 44.8 & 198 \\
\hline used & & 435 & 264 & 17.8 & 40.9 & 197 \\
\hline new & \multirow[t]{2}{*}{250} & 480 & 318 & 21.0 & 46.7 & 194 \\
\hline used & & 415 & 227 & 18.5 & 42.7 & 192 \\
\hline
\end{tabular}


Fig. 2. Typical stress-strain diagrams for new and used $14 \mathrm{MoV} 63$ steels, tensile test at $250^{\circ} \mathrm{C}$, stress vs longitudinal strain (a), stress vs diameter contraction strain (b).

Impact Notch Toughness. Again, as in the case of tensile properties, the reduction in impact toughness is not critical [8]. There is no reduction in impact energy of used steel when testing at $150^{\circ} \mathrm{C}$, and impact toughness is almost the same for new and used steel. Reduction in impact energy at room temperature is expressed only in crack propagation energy, not in crack initiation energy. Nil ductility transition temperature for this steel is above room temperature, and this explains the significantly higher values of impact toughness at $150^{\circ} \mathrm{C}$.

Local Fracture Approach. The local fracture approach defines critical parameters, which describe brittle fracture (cleavage) and ductile fracture (tearing) [9]. Determination of these parameters is based on theoretical, experimental and numerical procedures proposed by ESIS [6]. In the considered case, only ductile fracture is of importance because steel is exposed in service to elevated temperature.

Theoretical Basis of Local Fracture Approach. Process of ductile fracture initiation develops through three independent stages:

(i) void formation due to presence of inclusions;

(ii) void growth;

(iii) void coalescence [10]. 
Voids are formed during material loading under the critical normal stress inside the inclusions or at the boundary inclusion surface. Voids' formation is caused by breaking of interfaces between matrix and particles (inclusions and second phase particles). Next stage in ductile fracture development is growth of voids, and it is considered to be the most important stage. The growth of formed voids depends on the effect of the external load, which produces additional plastic strains and affects the hydrostatic stress component. The latter factors affect further growth of voids and eventual coalescence of voids.

Ductile fracture is described by numerous models. One of the most frequently applied is the model of Rice and Tracey [11], in which the growth of a void insulated within a volume is considered, as presented by the expression:

$$
\ln \left(\frac{R}{R_{0}}\right)=\int 0.283\left(\frac{3 \sigma_{m}}{2 \sigma_{e q}}\right) d \varepsilon_{e q}^{p} .
$$

Here, $R / R_{0}$ is the void growth rate, $R$ - stands for actual void size, $R_{0}$ - for initial void size. Void growth rate can be determined by integrating the right side from the initial value of equivalent deformation to its actual value $\varepsilon_{e q}^{p}$, for each point of calculated values of hydrostatic pressure $\sigma_{m}$ and equivalent stress $\sigma_{e q}$.

This model takes into consideration the stress triaxiality represented by the ratio of hydrostatic stress $\sigma_{m}$ and von Mises equivalent stress $\sigma_{e q}$, given by components of stress tensor $\sigma_{i j}$ :

$$
\begin{gathered}
\sigma_{m}=\frac{\sigma_{r r}+\sigma_{\theta \theta}+\sigma_{z z}}{3}=\frac{\sigma_{11}+\sigma_{22}+\sigma_{33}}{3}, \\
\sigma_{e q}=\sqrt{\frac{1}{2}\left[\left(\sigma_{11}-\sigma_{22}\right)^{2}+\left(\sigma_{22}-\sigma_{33}\right)^{2}+\left(\sigma_{33}-\sigma_{11}\right)^{2}\right]} .
\end{gathered}
$$

Experimental Analysis of Notched Specimens for the Local Fracture Approach. Design of tensile specimens for experimental analysis is given in [12]. Specimens are produced with notch root radius $R=10,4$, and $2 \mathrm{~mm}$. In this way, the triaxiality effect is taken into account. The critical void growth, determined as a local-approach parameter by the proposed procedure, does not depend on geometry. Ductile fracture is dominant at elevated (here, $250^{\circ} \mathrm{C}$ ) temperature testing, indicating that calculated critical void growth does not depend on temperature as well [8]. In further FEM calculations, we used the true stress - true strain curve obtained at the temperature for which calculation is performed. Strain parameter in this case is contraction of the diameter in specimen notch root.

Using the "load vs diameter contraction" records (Fig. 3), true stress vs true strain relationships can be determined for the new and used steel tested at $250^{\circ} \mathrm{C}$ (Fig. 4), which are to be compared with corresponding curves obtained by FEM calculation. The reduction in strength and plasticity of used steel is visible. True stress reduction $\left(\Delta \sigma_{F}\right)$ is the greatest for notch root radius $2 \mathrm{~mm}$, and reduction in plasticity $\left(\Delta \varepsilon_{F}\right)$ is most expressed for radius $10 \mathrm{~mm}$, indicating that stress 
concentration is involved in the local approach method. This can be explained by fracture mechanics approach because the critical triaxiality is achieved for plane strain conditions, as in the case of notch root radius $2 \mathrm{~mm}$. Used steel properties degradation produces faster void activation, followed by faster occurrence of critical growth rate and material fracture. For plane stress case, dominated for lower triaxiality level (notch root radius $10 \mathrm{~mm}$ ), the influence of strain is dominant. In order to obtain an average result, critical void growth should be determined for all three specimen geometries $(R=2,4$, and $10 \mathrm{~mm})[6]$.



Fig. 3

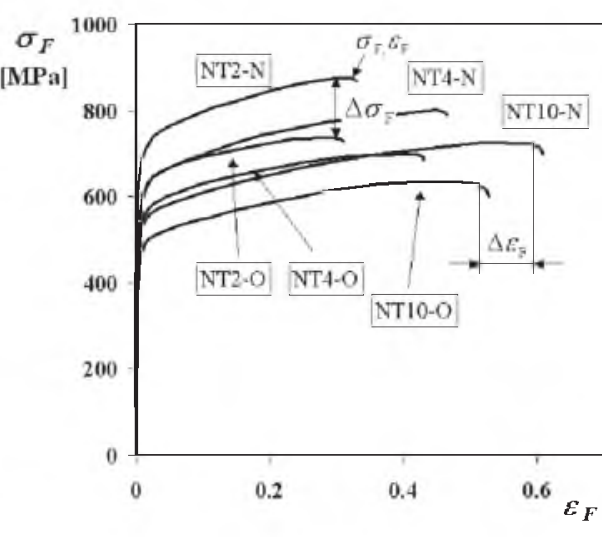

Fig. 4

Fig. 3. Load $(F)$ ys contraction of notch root diameter $(\Delta d)$, for new $(N)$ and used $(O)$ steel, notch radius $2 \mathrm{~mm}$ (NT2), $4 \mathrm{~mm}$ (NT4), and $10 \mathrm{~mm}$ (NT10).

Fig. 4. True stress $\left(\sigma_{F}\right)$ vs true strain $\left(\varepsilon_{F}\right)$ relationships for new $(N)$ and used $(O)$ steel specimens, with notch radius $2 \mathrm{~mm}$ (NT-2), $4 \mathrm{~mm}$ (NT-4), and $10 \mathrm{~mm}$ (NT-10).

Calculation of Local Approach Parameters. In order to determine void growth rate $R / R_{0}$ according to Eq. (1), the equivalent uniaxial strain $\bar{\varepsilon}_{F}$ and true stress $\bar{\sigma}_{F}$ values need to calculated by the following formulas:

$$
\begin{gathered}
\bar{\varepsilon}_{F}=2 \ln \left(\frac{d_{0}}{d_{F}}\right), \\
\bar{\sigma}_{F}=\frac{4 F_{F}}{\pi d_{F}^{2}} .
\end{gathered}
$$

The calculation of the above parameters of ductile fracture is carried out using a post-processor program [6]. The cavity growth rate $R / R_{0}$ is calculated in each mesh element using the equivalent uniaxial strain and true stress averaged values of the strains and stresses, respectively, over the Gauss points. Critical cavity growth rate $\left(R / R_{0}\right)_{c}$ can be obtained by replacing von Mises equivalent stress, $\sigma_{e q}$, in Eq. (2) and triaxial stress, $\sigma_{m}$, which represents hydrostatic stress, in Eq. (3). True stress-strain curves obtained by testing the specimens with three different notch root radii are compared with corresponding curves obtained by 
FEM analysis. When sufficient accordance between two sets of curves [6] is achieved, critical void growth rate can be calculated using Eqs. (1)-(3). The hydrostatic stress $\sigma_{m}$ value is determined from the maximum normal stress component obtained in a finite element critical node, positioned in the minimum cross section of specimen axes (marked by $C N$ in Fig. 5). The von Mises equivalent stress $\sigma_{e q}$ is calculated in the same node.

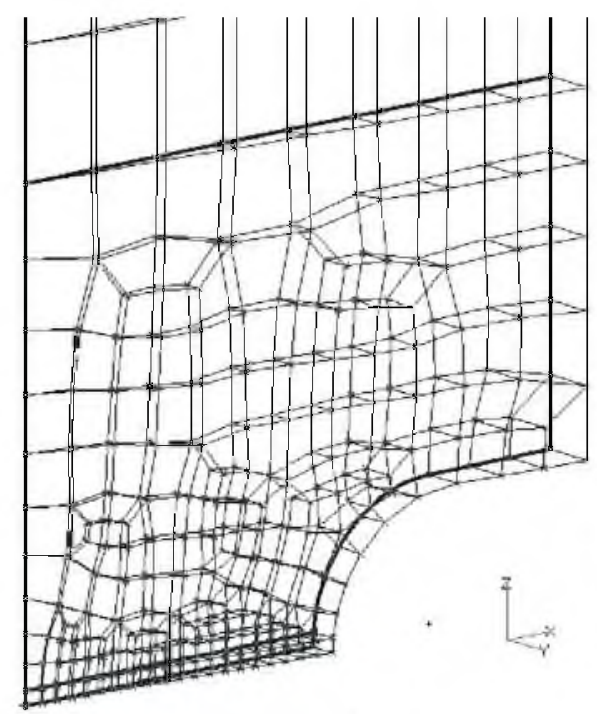

$a$

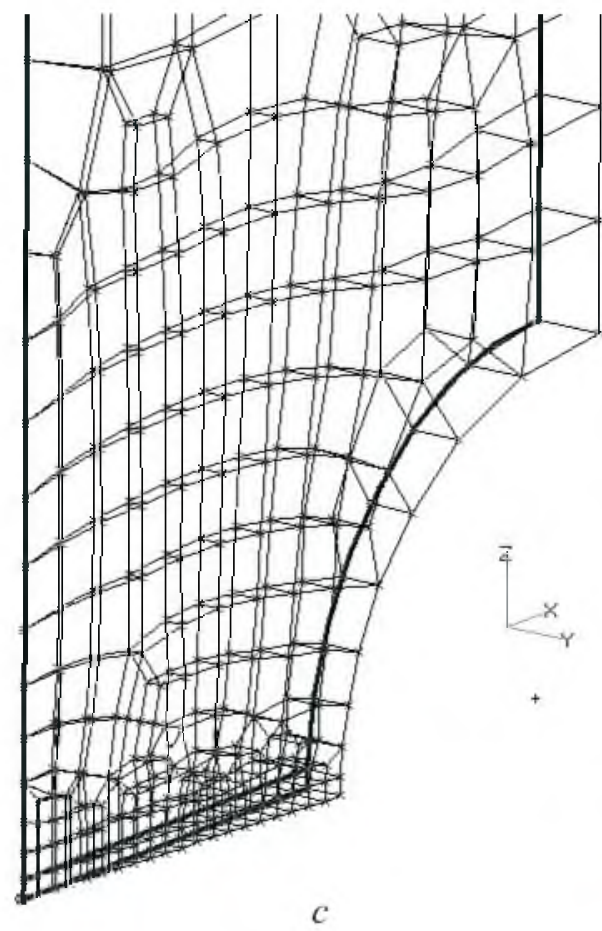



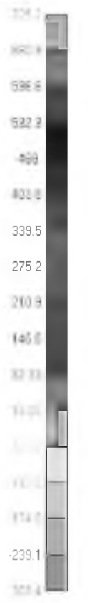

$b$

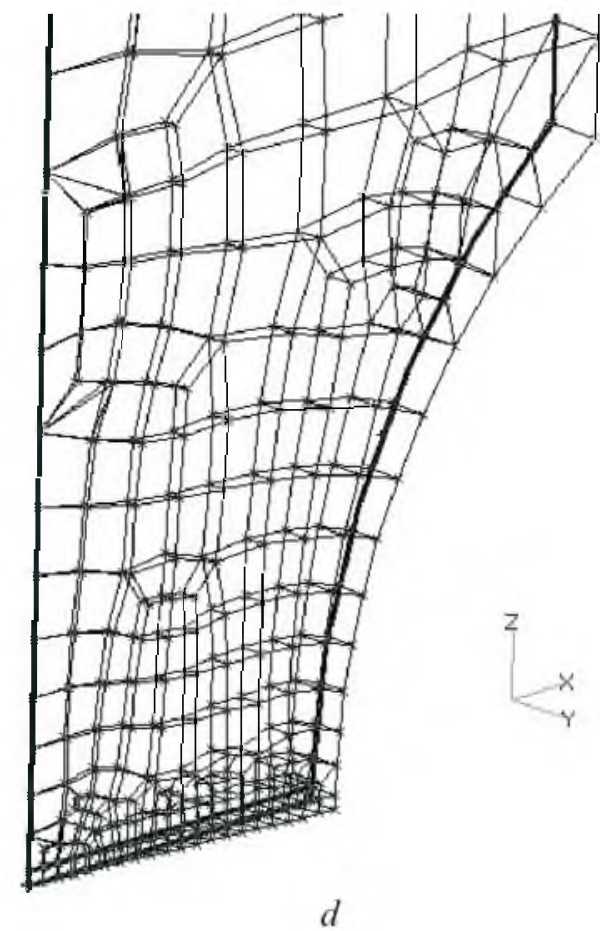

Fig. 5. Notched tensile specimen calculation: (a) mesh, notch root radius $R=2 \mathrm{~mm}$; (b) stress distribution, $R=4 \mathrm{~mm}$; (c) mesh, $R=4 \mathrm{~mm}$; (d) mesh, $R=10 \mathrm{~mm}$. 
Elastic-plastic analysis in NASTRAN software is used for FEM calculation with 3D elements. Upper specimen half is modeled as a wedge element, with angle of $5^{\circ}$, corresponding to $1 / 72$ part of upper specimen part (Fig. 5). This affects the shape of finite elements mesh, producing wedge type elements around axes, and the other elements are of brick type.

Calculation by the local criterion yields the material characteristic representing the local stressed state, which corresponds to the critical void growth and to the onset of unstable fracture. It has a convenient form, applicable in FEM calculation. When high stress level is found in a structure and void growth rate $R / R_{0}$ is verified, failure of the structure can be expected at the critical $\left(R / R_{0}\right)_{c}$ level. From the engineering point of view, this verification should be performed for the maximum load, e.g., for the ultimate tensile strength, $\left(R / R_{0}\right)_{m}$, as the indication of critical behavior of the structure.

Experiments have been performed with five specimens of new and used steel of various geometries for determination of values for critical void growth rate (the final fracture) $\left(R / R_{0}\right)_{c}$ and void growth rate $\left(R / R_{0}\right)_{m}$, corresponding to the ultimate tensile strength (the maximum load). Columns $4-5$ in Table 5 present average values of measurement of five specimens taken from new $(N)$ and used steel $(O)$ for three geometries (notch root radius $10 \mathrm{~mm}, 4 \mathrm{~mm}$, and $2 \mathrm{~mm}$ ). Columns 8-9 present average final values of critical void growth rate $\left(R / R_{0}\right)_{\mathcal{C}}$ and void growth rate $\left(R / R_{0}\right)_{m}$, for the maximum load. Solution of Eq. 1 produces $\ln \left(R / R_{0}\right)$, and thus values of void growth rate $R / R_{0}$ presented in this form start from 1 , insofar as $\ln \left(R / R_{0}\right)=0$. For this reason, the values $\left(R / R_{0}-1\right)$ should be used for comparison of the results obtained.

$\mathrm{T}$ a b 1 e 5

Values of Void Growth Rate for the Final Fracture $\left(R / R_{0}\right)_{c}$ and for the Maximum Load $\left(R / R_{0}\right)_{m}$

\begin{tabular}{|c|c|c|c|c|c|c|c|c|c|c|}
\hline \multirow{2}{*}{$\begin{array}{c}\text { Speci- } \\
\text { men }\end{array}$} & \multicolumn{3}{|c|}{ Average values for 5 specimens } & \multicolumn{7}{|c|}{ Average final values } \\
\cline { 2 - 10 } & $\ln \left(\frac{R}{R_{0}}\right)_{c}$ & $\ln \left(\frac{R}{R_{0}}\right)_{m}$ & $\left(\frac{R}{R_{0}}\right)_{c}$ & $\left(\frac{R}{R_{0}}\right)_{m}$ & $\ln \left(\frac{R}{R_{0}}\right)_{c}$ & $\ln \left(\frac{R}{R_{0}}\right)_{m}$ & $\left(\frac{R}{R_{0}}\right)_{c}$ & $\left(\frac{R}{R_{0}}\right)_{m}\left(\frac{R}{R_{0}}\right)_{c}-1$ & $\left(\frac{R}{R_{0}}\right)_{m}-1$ \\
\hline 1 & 2 & 3 & 4 & 5 & 6 & 7 & 8 & 9 & 10 & 11 \\
\hline $10 \mathrm{~N}$ & 0.6136 & 0.0792 & 1.8470 & 1.0824 & 0.5131 & 0.0734 & 1.68 & 1.08 & 0.68 & 0.08 \\
\hline $4 \mathrm{~N}$ & 0.5467 & 0.0751 & 1.7275 & 1.0780 & & & & & & \\
\hline $2 \mathrm{~N}$ & 0.3790 & 0.0659 & 1.4609 & 1.0682 & & & & & & \\
\hline $10 \mathrm{O}$ & 0.5612 & 0.0742 & 1.7670 & 1.0770 & 0.4526 & 0.0688 & 1.59 & 1.07 & 0.59 & 0.07 \\
\hline 40 & 0.4855 & 0.0702 & 1.6250 & 1.0727 & & & & & & \\
\hline $2 \mathrm{O}$ & 0.3112 & 0.0621 & 1.3650 & 1.041 & & & & & & \\
\hline
\end{tabular}

The bearing capacity of steel is exhausted as soon as the maximum load is reached, e.g., it corresponds to the ultimate tensile strength. For that, relevant void growth rate should be taken as the value $\left(R / R_{0}\right)_{m}$, and not as critical value defined by the local approach $\left(R / R_{0}\right)_{c}$. This also explains the difference in values $\left(R / R_{0}\right)_{c}-1$ and $\left(R / R_{0}\right)_{m}-1$ in Table 5 . 
Crack Resistance. J-Integral. Single-edge notched bending specimens SE(B) type - have been produced from pipe in direction $L-R$. For new steel, specimes are sized $B=17.5 \mathrm{~mm}$ in thickness and $W=33.6 \mathrm{~mm}$ wide, with fatigue precrack of final length $a_{0}=19.86 \mathrm{~mm}$. Specimens from used steel were of $B=17.5 \mathrm{~mm}, W=19.8 \mathrm{~mm}$, with fatigue precrack of final length $a_{0}=12.79 \mathrm{~mm}$. Testing is performed according to ESIS Recommandations P1-92 and standard ASTM E1152, based on elastic-plastic fracture mechanics. Thus, crack growth could be monitored also in the plastic range, and the critical $J$-integral value, $J_{\text {Ic }}$, obtained as a measure of fracture toughness, which can be used to calculate the critical stress intensity factor, $K_{\mathrm{Ic}}$. Tests are performed at $150^{\circ} \mathrm{C}$. Single specimen compliance method with successive unloading is used (ASTM E1152). In this way, $J-R$ curve, e.g., relationship $J-\Delta a$ (Fig. 6) is obtained, from which the critical value for crack initiation can be determined.
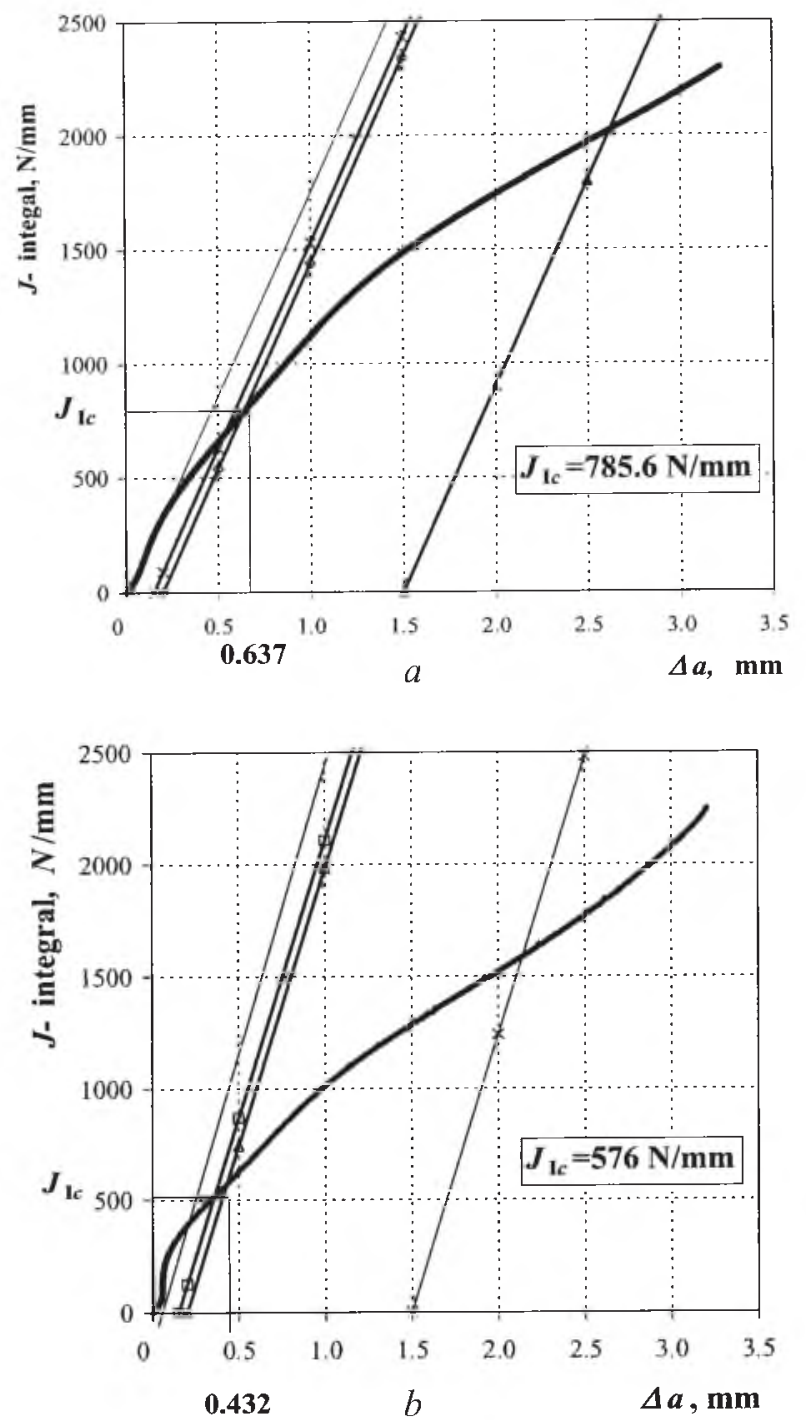

Fig. 6. $J-R$ curves $(J-\Delta a)$, for new (a) and used (b) 14MoV6 3 steel tested at $150^{\circ} \mathrm{C}$. 
By measuring slope of unloading line it is possible to calculate the crack extension, $\Delta a$, in one step. In general, crack starts to grow when the maximum load in record "load $F$ vs load line displacement $\delta$ " is reached (Fig. 7). It is possible to obtain two sets of data: $F-\delta)$;

(i) energy spent on crack extension in individual steps (area under record

(ii) change of compliance (change of unloading line slope).
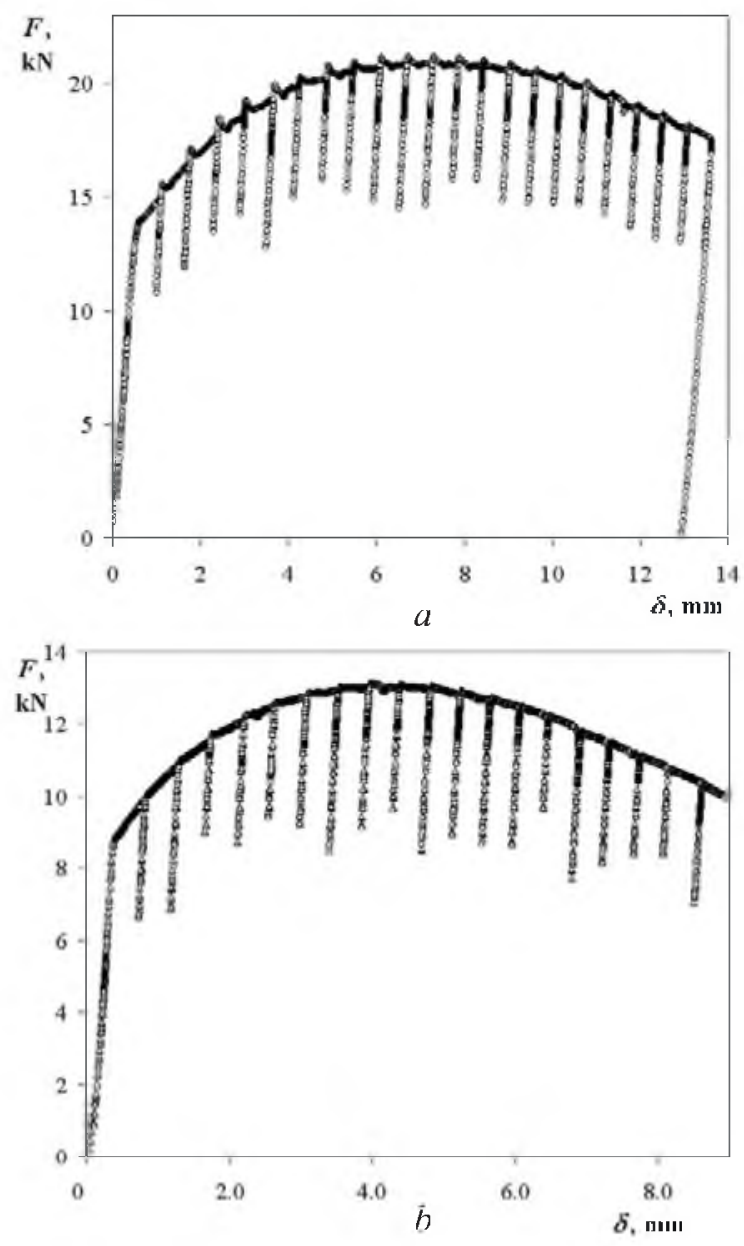

Fig. 7. Records "load $F$ vs load line displacement $\delta$ " obtained at $150^{\circ} \mathrm{C}$ by single specimen successive unloading method, for new (a) and used (b) 14MoV6 3 steel.

Crack extension $\Delta a_{i}$ in one step is calculated from the ratio $\delta / F$ taken as difference in unloading line slopes, applying formula:

$$
\Delta a_{i}=\Delta a_{i-1}+\left(\frac{b_{i-1}}{2}\right)\left(\frac{C_{i-1}-C_{i}}{C_{i}}\right),
$$

where $a_{i-1}$ stands for the previous crack length, $C_{i}=\tan \alpha_{i}$ - for the considered unloading line slope, and $C_{i-1}=\tan \alpha_{i-1}$ - for the previous unloading line slope. 
From directly recorded relationship $F-\delta$ (Fig. 3), $J$-integral can also be calculated by formula

$$
J_{i}=\left[J_{i-1}+\left(\frac{2}{b}\right) \frac{A_{i}-A_{i-1}}{B}\right]\left[1-\frac{a_{i}-a_{i-1}}{b_{i}}\right]
$$

where $A$ is the area below the curve, $B$ is specimen thickness, and $b$ is the ligament length.

Using parameters calculated by Eqs. (6) and (7), the relationship $J-\Delta a$ is obtained (Fig. 6), and the critical $J$-integral value, $J_{\mathrm{Ic}}$, can be then obtained in the cross section of fitted parabolic line and ordinate for $0.2 \mathrm{~mm}$ crack length. The regression line for $J_{\mathrm{Ic}}$ evaluation according to ASTM E813 is also given in Fig. 6.

From the critical $J$-integral value $J_{\mathrm{I} c}$ it is possible to calculate the critical stress intensity factor (plane strain fracture toughness), $K_{\mathrm{I} c}$, from

$$
K_{\mathrm{I} c}=\sqrt{\frac{J_{\mathrm{I} c} E}{1-v^{2}}} .
$$

The obtained values of critical $J_{\text {Ic }}$ integral and critical stress intensity factor, $K_{\mathrm{Ic}}$, are given in Table 6 .

$\mathrm{T}$ a b 1 e 6

Fracture Toughness Values of new and Used $14 \mathrm{MoV} 63$ Steel at $150^{\circ} \mathrm{C}$

\begin{tabular}{|c|c|c|c|c|c|}
\hline Steel & $\begin{array}{c}\text { Temperature } \\
\left({ }^{\circ} \mathrm{C}\right)\end{array}$ & $\begin{array}{c}\text { Young's } \\
\text { modulus } E, \\
\mathrm{GPa}\end{array}$ & $\begin{array}{c}\text { Poisson's } \\
\text { ratio } v\end{array}$ & $\begin{array}{c}\text { Critical } J \text {-integral } \\
\text { value } J_{\mathrm{I} c} \\
\mathrm{~kJ} / \mathrm{m}^{2}\end{array}$ & $\begin{array}{c}\text { Critical stress } \\
\text { intensity factor } K_{\mathrm{I} c}, \\
\mathrm{MPa} \sqrt{\mathrm{m}}\end{array}$ \\
\hline new & 150 & 198 & 0.3 & 170 & 192 \\
\hline used & 150 & 197 & 0.3 & 130 & 160 \\
\hline
\end{tabular}

Fatigue Crack Growth Rate $(d a / d N)$. This testing is performed for determination of coefficients $C$ and $n$ in the Paris equation for fatigue crack growth, as well as of threshold value. Standard Charpy specimen with V-notch had been tested by variable bending with sinusoidal cycle and stress ratio $R=0.1$ using the resonant high frequency pulsator CRACKTRONIC.

The mean load and amplitude were controlled with an accuracy of $\pm 5 \mathrm{~N} \cdot \mathrm{cm}$. Testing was performed in compliance with standard ASTM E-647-88a on determination of fatigue crack growth rate, $d a / d N$, and stress intensity factor range, $\Delta K$. This standard imposes two limitations:

(i) fatigue crack growth rate must be higher than $10^{-8} \mathrm{~m} /$ cycle in order to avoid fatigue threshold region, $\Delta K_{t h}$;

(ii) the amplitude of load must be constant.

Foil crack gauges RUMUL RMF A-5 of measuring length $5 \mathrm{~mm}$ are bonded on machined specimens, enabling monitoring of crack growth on fatigue test device FRACTOMAT operating by the potential drop principle. Crack growth is followed by foil separation, producing the change of electric resistance (Fig. 8). 




Fig. 8. Scheme of crack growth measurement by the potential drop in crack gauge foil

During testing the number of cycles was automatically registered for each $0.05 \mathrm{~mm}$ of crack extension. Crack growth rate $d a / d N$ is calculated based on this registration.

Dependence "crack growth rate $d a / d N$ vs stress intensity factor range $\Delta K$ " can be expressed using the Paris coefficients $C$ and $n$. Stress intensity factor range $\Delta K$ for the actual crack length a depends on the specimen geometry, crack length and variable load range, $\Delta F=F_{g}-F_{d}$ ( $F_{g}$ is the upper load in a cylce and $F_{d}$ is the lower load). It can be calculated from the following formulas:

$$
\begin{gathered}
\Delta K=\frac{\Delta P L}{B \sqrt{W^{3}}} f(a / W) \\
f(a / W)=\frac{3 \sqrt{\frac{a}{W}}}{2\left(1+2 \frac{a}{W}\right)\left(1-\frac{a}{W}\right)^{3 / 2}}\left[1.99-\frac{a}{W}\left(1-\frac{a}{W}\right)\left(2.15-3.93 \frac{a}{W}+2.7\left(\frac{a}{W}\right)^{2}\right)\right] .
\end{gathered}
$$

Here, $L$ is span, $B$ is the specimen thickness, $W$ is the specimen width, and $a$ is the crack length.

Calculated values for the Paris equation, presented in the form $\log d a / d N$ vs $\log \Delta K$, are shown in Fig. 9 and given in Table 7 for new and used steel.

$\mathrm{T}$ a b 1 e 7

Fatigue Crack Growth Parameters for New and Used 14MoV6 3 Steel at $20^{\circ} \mathrm{C}$

\begin{tabular}{|c|c|c|c|c|}
\hline Steel & Temperature $\left({ }^{\circ} \mathrm{C}\right)$ & $\begin{array}{c}\text { Paris } \\
\text { coefficient, } C\end{array}$ & $\begin{array}{c}\text { Paris } \\
\text { exponent, } n\end{array}$ & $\begin{array}{c}\text { Threshold value } \\
K_{t h}, \mathrm{MPa} \sqrt{\mathrm{m}}\end{array}$ \\
\hline new & 20 & $1.47 \cdot 10^{-15}$ & 6.114 & 7.454 \\
\hline used & 20 & $2.06 \cdot 10^{-14}$ & 4.936 & 7.231 \\
\hline
\end{tabular}




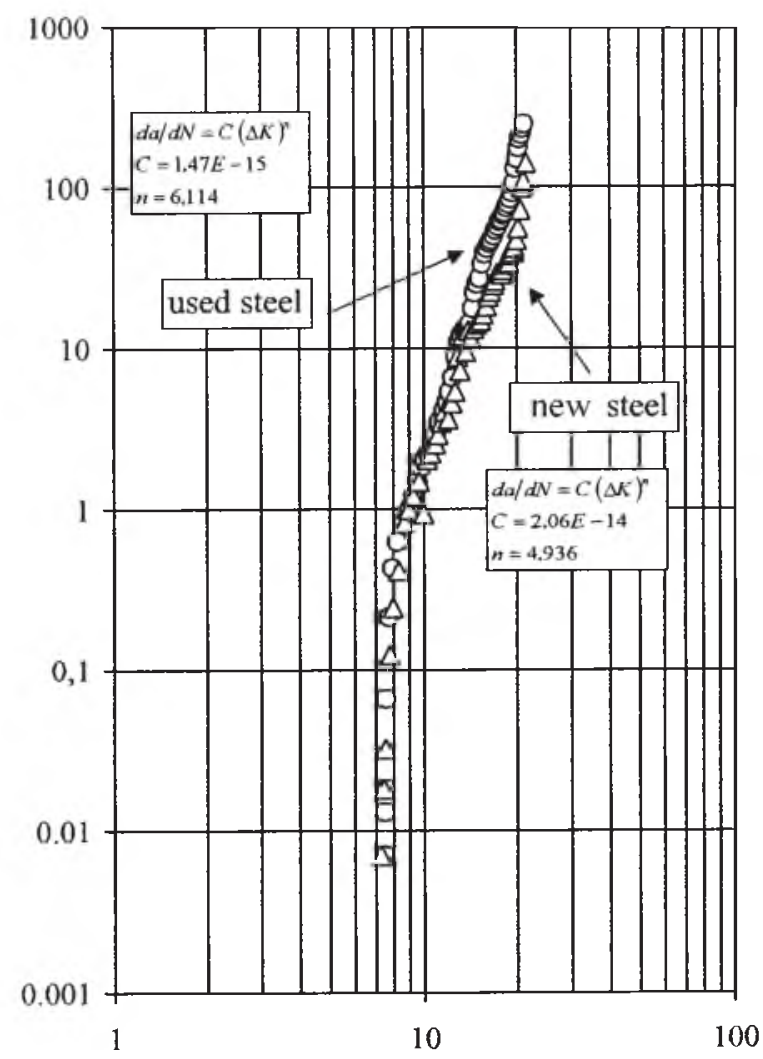

Fig. 9. Crack growth rate $d a / d N$ vs stress intensity factor range $\Delta K$ for new and used steel.

Metalographic Examination. Light metallography had been performed with samples, taken from new and used steel, in order to compare the microstructural change after 117,000 service hours. Finer microstructure of new steel samples is clearly visible for magnification $\times 200$, and more expressed for magnification $\times 500$ (Fig. 10). Due to exposure to high temperature and high stresses, used steel becomes deteriorated by grain coarsening. On the other hand, it is possible to find voids between grains in different positions, uniformly distributed in the considered area. The clear difference in ferrite-pearlite microstructure vanishes slowly. This is finally confirmed by higher magnification of $\times 1000$. It is possible to conclude that deterioration level in the used steel is close to the initial creep stage. For that, it is recommended to reduce temperature and pressure in the steam pipeline in the next limited operation and to replace pipes after that. Having in mind that examined samples are taken from straight part of the pipeline, the situation in the knee zone can be considered as more critical.

Ductile behavior of new steel is confirmed by scanning electron examination of fractured new steel specimen NT10 with notch root raidus $10 \mathrm{~mm}$ tested at $250^{\circ} \mathrm{C}$ (Fig. 11). Inclusions, from which void formed, can be recognized in the bottom of dimples. Formed voids coalesce during fracture process up to the final breaking. 
Fracture Toughness and Crack Resistance..
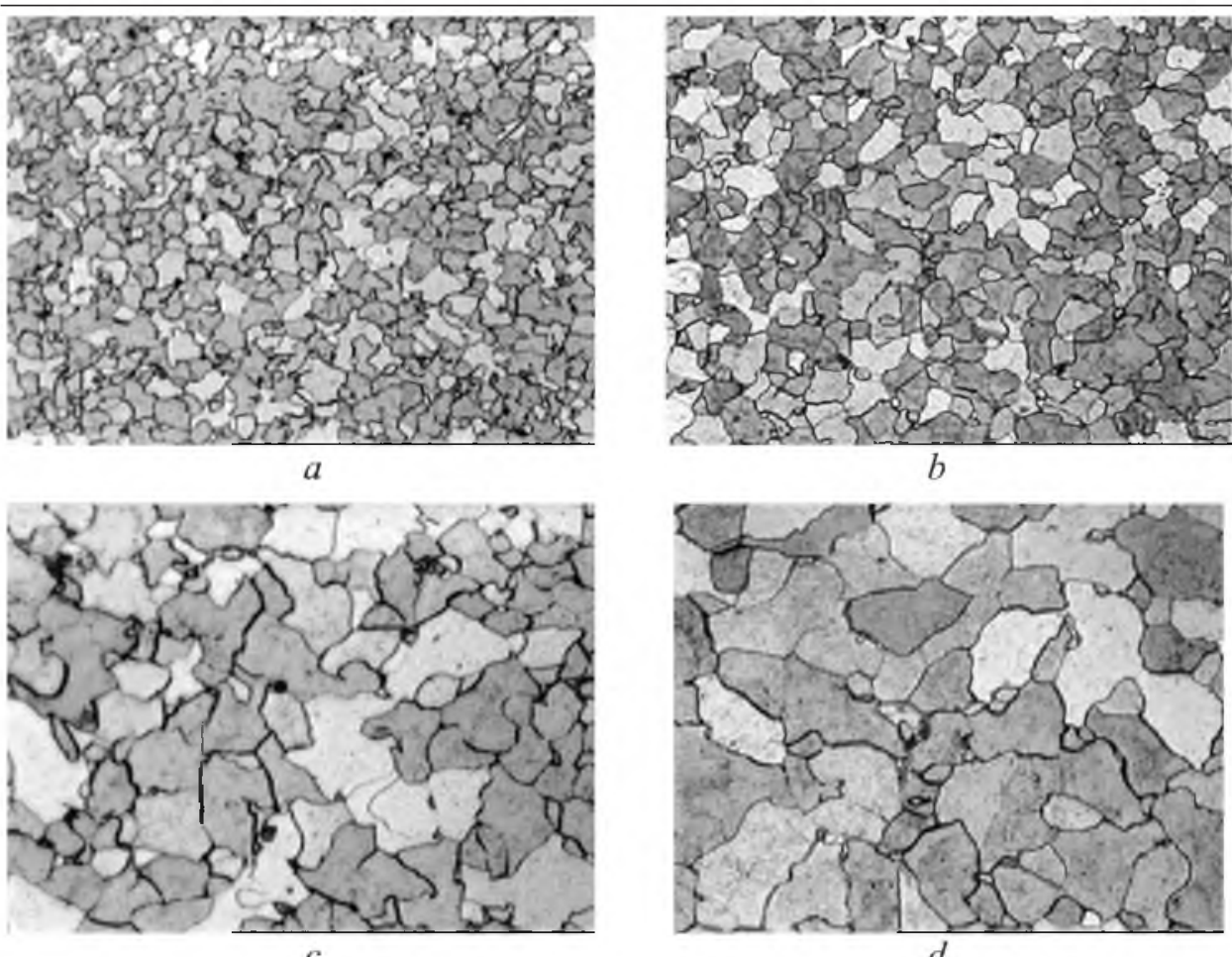

$c$
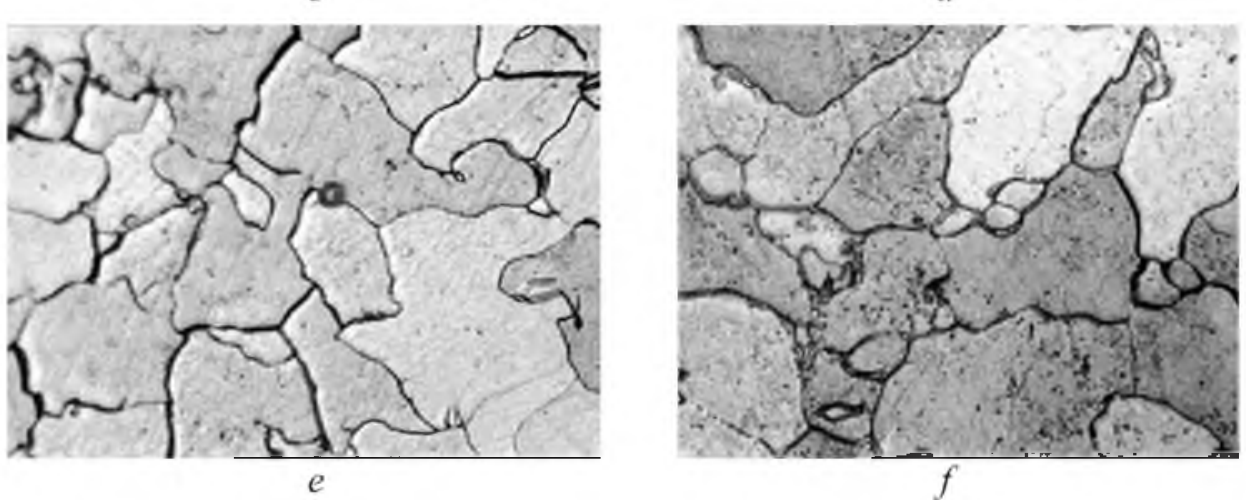

Fig. 10. Microstructure of samples taken from pipe outer surface: $(a, c, e)$ new steel and $(b, d$, $f)$ used steel; $(a, b) \times 200 ;(c, d) \times 500 ;(e, f) \times 1000$.
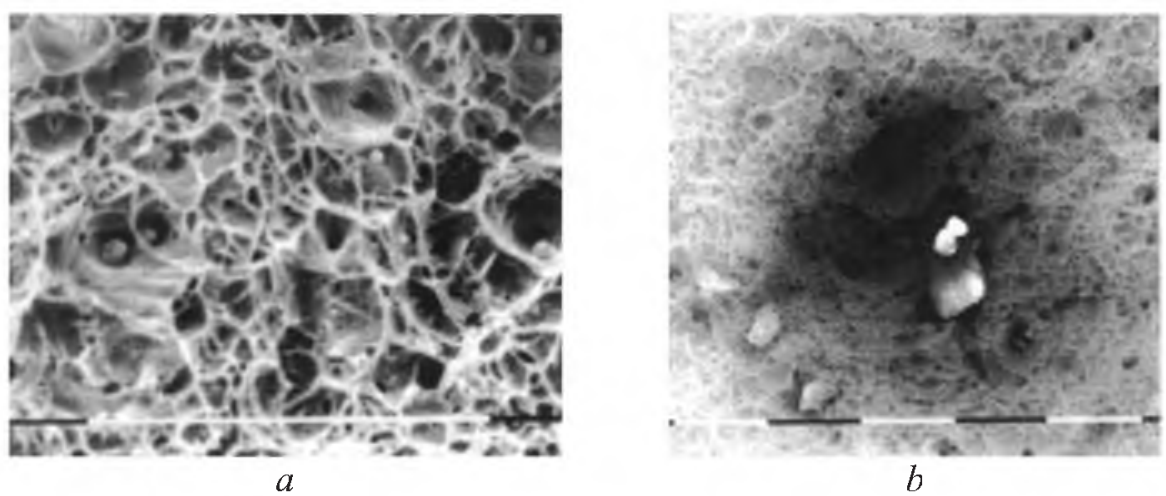

Fig. 11. Ductile fracture of new $14 \mathrm{MoV} 63$ steel: (a) indication $1 \mathrm{~mm}$ and (b) indication $10 \mu \mathrm{m}$. 
Analysis of Results. Tensile properties of used steel are reduced as compared to the corresponding values of new steel for both testing temperatures $\left(150\right.$ and $250^{\circ} \mathrm{C}$ ), as given in Table 4 . This reduction percentage is presented in Table 8. Tensile properties' reduction is more pronounced at higher testing temperature $\left(250^{\circ} \mathrm{C}\right)$. The reduction is the most pronounced for the yield stress.

$\mathrm{T}$ a b 1 e 8

Reduction of Tensile Properties of Used Steel as Compared to that of New Steel (\%)

\begin{tabular}{|c|c|c|c|c|}
\hline $\begin{array}{c}\text { Temperature } \\
t,{ }^{\circ} \mathrm{C}\end{array}$ & $\begin{array}{c}\text { Ultimate tensile } \\
\text { strength } R_{m}, \%\end{array}$ & $\begin{array}{c}\text { Yield stress } \\
R_{e}, \%\end{array}$ & $\begin{array}{c}\text { Elongation } \\
\varepsilon_{\ell}, \%\end{array}$ & $\begin{array}{c}\text { Contraction } \\
\varepsilon_{d}, \%\end{array}$ \\
\hline 150 & 11.2 & 22 & 14 & 8.71 \\
\hline 250 & 13.5 & 29 & 12 & 8.77 \\
\hline
\end{tabular}

Reduction in the void growth rate $R / R_{0}$ is presented in Table 9 for the final fracture and for the maximum load values in percentage. As it is already said, for the proper analysis of steel deterioration, the value corresponding to the maximum load should be used, e.g., $\left(R / R_{0}\right)_{m}-1$.

$\mathrm{T}$ a b 1 e 9

Reduction of Void Growth Rate $R / R_{0}$ for the Used Steel (\%)

\begin{tabular}{|c|c|c|c|c|c|}
\hline $\ln \left(R / R_{0}\right)_{c}$ & $\ln \left(R / R_{0}\right)_{m}$ & $\left(R / R_{0}\right)_{c}$ & $\left(R / R_{0}\right)_{m}$ & $\left(R / R_{0}\right)_{c}-1$ & $\left(R / R_{0}\right)_{m}-1$ \\
\hline 11.8 & 6.3 & 5.5 & 0.5 & 13.7 & 6.5 \\
\hline
\end{tabular}

Comparison of properties at $250^{\circ} \mathrm{C}$ shows that the reduction is more expressed for tensile strength $R_{m}(13.5 \%$, Table 6$)$, than for corresponding void growth rate $\left(R / R_{0}\right)_{m}$ given through $\left(R / R_{0}\right)_{m}-1(6.5 \%$, Table 9). This is the indication of conservatism of classical approach. Moreover, ductile fracture criterion, applied in local approach, is directly applicable in FE method, defining limit stress value in a structure.

Conclusions. The agreement of records obtained by tensile testing of notched specimens with diagrams obtained by the FEM analysis is a prerequisite for calculation of local criterion for ductile fracture. In this way, the material characteristics, precisely describing material properties, are available for modern computational methods, such as FEM.

Described properties of the local fracture approach enabled more precise evaluation of deterioration of steel 14MoV6 3 properties after long-term exposure to elevated temperatures. Obtained results have shown that the maximum load in tensile test, and not the value corresponding to the final fracture, is a relevant one for the comparison of new and used steel properties. The reduction in void growth rate obtained in the conducted tests is only $6.5 \%$, whereas, being expressed in term of tensile strength, it is $13.5 \%$, and finally, being expressed through yield stress, it is as high as $39 \%$.

It is possible to conclude that the steel under study can be used for future service under condition of prescribed in-service inspections, notwithstanding that the specified service life is spent. The economical benefit could be significant. Anyhow, further refinement of the local fracture approach is necessary for its practical application. 


\section{P ез о ме}

Досліджується проблема передчасного руйнування паропроводів (сталь $14 \mathrm{MoV} 63$ ) із розрахунковим ресурсом 100 тис. год за температури $540^{\circ} \mathrm{C}$. При виготовленні експериментальних зразків використовувалася сталь у первинному стані та після 117 тис. год експлуатації. Використання локального підходу механіки руйнування і металографічного аналізу поряд із класичними методами (випробування на розтяг, тріщиностійкість, міцність від утомленості) дозволило більш точно оцінити деградацію властивостей сталі під дією високих температур і напружень. Обгрунтовано необхідність подальшого розвитку локального підходу до прогнозування умов руйнування матеріалів при тривалій експлуатації в умовах високих температур.

1. H. Kaes, Erfahrungen mit dem Stahl 14MoV6 3, in: Bericht des VGBAusschusses für Materialfragen, Essen (1966).

2. W. Arnswald und H. Kaes, Verwendung des Stahles 14 MoV6 3 für Rohrleitungen, VGB Konferenz (1985), SS. 356-358.

3. H. Kessler und W. Hoppe, Teilaustausch von HD- und HZU-Leitungen in einem $2 \times 300 \mathrm{MW}$ in Griechenland, Lebensdauer von Rohrleitungen in Kraftwerken, Mannesmann Anlagebau AD, Düsseldorf (1987), SS. 373-385.

4. H. Weber, H. Kessler, und H. Musch, "Restlebensdauer- und Schadensanalysen von Rohrleitungssystemen im Kraftwerksbau - das Know-How von Mannesmann," Lebensdauer von Rohrleitungen in Kraftwerken, Mannesmann Anlagenbau, Düsseldorf, 5 (1987).

5. A. Pineau, "Review of fracture micromechanisms and a local approach to predicting crack resistance in low strength steels," in: Advances in Fracture Research, Pergamon Press (1981), Vol 2, pp. 553-577.

6. ESIS P6-98. Procedure to Measure and Calculate Material Parameters for the Local Approach to Fracture Using Notched Tensile Specimens, European Structural Integrity Society (ESIS) (1998).

7. F. Mudry and M. Di Fant, A Round Robin on the Measurement of Local Criteria, IRSID-SG Report, RE 93-319 (1993).

8. M. Zrilic and R. Aleksic, "The effect of long term exposure to elevated temperature on steam line steel properties," Thermal Science, 7, No. 1, 33-46 (2003).

9. M. Bethmont, "The principles of the local approach of fracture," in: 5th International Fracture Mechanics Summer School, EMAS (1990), pp. 45-70.

10. V. Tvergaard, "Ductile fracture by cavity nucleation between larger voids," J. Mech. Phys. Solids, 30, No. 4, 265-286 (1982).

11. J. R. Rice and D. M. Tracey, "On the ductile enlargement of voids in triaxial stress fields," J. Mech. Phys. Solids, 17, 201-217 (1969).

12. M. Zrilic, M. Rakin, A. Sedmak, and S. Sedmak, "Assessment of in-service degradation of steam pipeline steel by local approach method," in: Life Assessment and Management for Structural Components (Resource 2000), Kiev (2000), Vol. 1, pp. 247-253. 